\title{
EFFECT OF DISTANCE BETWEEN LINES OF DRIP IRRIGATION ON CORN YIELD IN SANDY SOILS
}

\author{
HUSSEIN, A.A., A.S.H. MOHAMMED and T.S. MOHAMMED
}

- On Farm irrigation Research Dept. Agr.Eng.Inst.ARC, Dokki, Giza, Egypt.

(Manuscript received 31 October 2018)

\begin{abstract}
$\mathrm{T}$ his study aims at determining the effect of drip lateral spaces and the full and deficit irrigation on corn yield, The water use efficiency under new land conditions during summer season of 2016 was evaluated. The experiment was conducted in privet farm (green revolution Km31Egypt-Alexandria road after the intelligent village). The farm has the latitude of $30^{\circ} 04^{\prime} 37.0 \mathrm{~N}$ the longitude of $30^{\circ} 59^{\prime} 53.5 \mathrm{E}$. Single hybrid (Giza /131) corn was used in this study. Irrigation treatments consisted of three different lateral spacing as (A: $0.60 \mathrm{~m}, \mathrm{~B}: 1.20 \mathrm{~m}$, and C: $1.80 \mathrm{~m})$ and two water level $\left(\mathrm{I}_{1}=100 \%, \mathrm{I}_{2}=70 \%\right)$ of water requirements. The study reveal that: The highest seasonal water use was determined in the full irrigation ( $\mathrm{I}_{1100} \%$ ), level (607 $\mathrm{mm} /$ season), and the lowest water use was found in the deficit irrigation $\left(\mathrm{CI}_{2} 70 \%\right)$, level $\left(428 \mathrm{~mm} /\right.$ season). The hig.A.S.S ${ }^{1}$ hest grain yield was obtained under $\left(\mathrm{BI}_{1100} \%\right)$ treatment with (4912 $\mathrm{kg} / \mathrm{Fe})$, and the lowest yield was found in the plant row (1.80 $\mathrm{m}$ ) away from the drip lateral in ( $\mathrm{C}_{270} \%$ ) treatment with (2504 $\mathrm{kg} / \mathrm{Fe}$. Yield from the $1.20 \mathrm{~m}$ ) spacing with full irrigation treatment $\mathrm{BI}_{1100} \%$ was significantly higher than in the other two spacing as $(A=60 \mathrm{~cm}, C=180 \mathrm{~cm})$. According to the research results, preferable lateral spacing for corn plant was found to be $1.20 \mathrm{~m}$. The highest water use efficiency (WUE) was found in $\mathrm{BI}_{170} \%\left(1.89 \mathrm{~kg} / \mathrm{m}^{3}\right)$ and the lowest one was found in the plant row $90 \mathrm{~cm}$ away from the drip lateral in $\mathrm{CI}_{2} 70 \%\left(1.39 \mathrm{~kg} / \mathrm{m}^{3}\right)$. Thus a lateral spacing of $120 \mathrm{~cm}$ (one drip lateral per two crop rows), flow rate $8 \mathrm{~L} / \mathrm{h} / \mathrm{m}$, (dripper flow rat $4 \mathrm{l} / \mathrm{h}$. dripper spaced $0.50 \mathrm{~m}$ ) was recommended for drip-irrigated corn under the Egyptian climatic conditions.
\end{abstract}

Keywords: Drip irrigation, Deficit irrigation, Preferable lateral spacing, Water use efficiency.

\section{INTRODUCTION}

Irrigation is today the primary consumer of fresh water on earth (Shiklomanov, 1998) but the increasing populations and expanding development are pushing our water resource management systems to be more productive with less water. Despite limited water resources in the world. Water management must be improved in order to fully solve it, or to reduce the severity of water shortage. Thus, agriculture has the greatest potential to solve the problem of global water scarcity. (Longo and Spears, 2003). Drip irrigation has been used for agricultural production for about the past 35 years. Drip irrigation has advantages over more traditional practices 
such as surface and sprinkler irrigation due to reduced labor requirements and its ability to conform to irregularly shaped fields. It is also much more efficient than sprinkler or surface irrigation (Camp, 1998). The reasons for the growing popularity of drip irrigation are several. Drip irrigation offers improved yields, requires less water, decreases the cost of tillage, and reduces the amount of fertilizer and other chemicals to be applied to the crop. Because drip irrigation makes it possible to place water precisely where it is needed and to apply it with a high degree of uniformity at very low flow rates, it lessens both surface runoff and deep percolation. These features make drip irrigation potentially much more efficient than other irrigation methods, which can translate to significant water savings (Hanson et al., 1994). Since the initial installation costs for drip irrigation are high, it has not been considered a viable economic option for field row crops, such as corn. However, increasing the spacing of dripline laterals would be one of the most significant factors in reducing the high overall investment costs of drip irrigation (Lamm et al., 1997). (Liu et al 2018) at least $14 \%$ of more maize production could be achieved through drip-irrigation systems in Heilongjiang Province compared to rainfed conditions. Sub-humid region drip-irrigation is increasingly applied in maize production. It is important to quantify irrigation requirements during different growth stages under different climatic conditions. Lamm et al. (1997) carried out a 2-year study on a Keith silt loam soil in northwest Kansas to determine the optimum drip line lateral spacing for irrigated corn using subsurface drip lines installed at a depth of $40-45 \mathrm{~cm}$ in a direction parallel to the corn rows. Average corn yields were 13.6, 12.8, and $12.2 \mathrm{Mg} /$ ha for drip line spacing of 1.5, 2.3, and $3.0 \mathrm{~m}$, respectively for a seasonal-irrigation amount of $462 \mathrm{~mm}$. Yields decreased to 10.8 and $9.3 \mathrm{Mg}$ / ha when irrigation was reduced by 33 and $50 \%$ for the wider 2.3 and $3.0 \mathrm{~m}$ drip line spacings, respectively. The highest yield, highest water use efficiency, and lowest year-to-year variation was obtained by the $1.5 \mathrm{~m}$ dripline spacing. Spurgeon and Manges (1991) reported no significant differences in corn yields among spacing treatments ranging from 0.75 to $3.0 \mathrm{~m}$ in a wet season (1989) at Garden City, Kansas. However, there was a $1.3-3.8 \mathrm{Mg} /$ ha range in yields 1990 and 1991, respectively (Spurgeon and Makens, 1991). The drip lines in this study were perpendicular to the corn rows. As a result, a corn plant could be as much as $1.5 \mathrm{~m}$ from a drip line for the 3.0m dripline spacing. (Sefer et al., 2011).Found that the average corn grain yields varied from 1.93 to $10.4 \mathrm{t}$ /ha and the highest water use efficiency $\left(1.77 \mathrm{~kg} / \mathrm{m}^{3}\right.$ ). Hussein and Dewidar (2018) shown that the adoption of modern irrigation systems combined with deficit irrigation strategies can improve both the irrigation water use efficiency and quality of tomato fruits. Kruse and Israeli (1987) examined subsurface drip irrigation using a $1.5 \mathrm{~m}$ dripline spacing for corn 
production in Colorado. They found considerable yield variation with distance from the dripline, and they concluded that it was important to center drip lines between corn rows to assure good production. Corn is one of the most important crops in Egypt. Common irrigation methods used for corn production in this region are wild flooding, furrow and sprinkler irrigation. In general, the farmers over irrigate, resulting in high water losses and low irrigation efficiencies, thus creating drainage and salinity problems (Yazar et al., 2002). The objectives of this study were to determine the effects of different lateral spacings and the full and deficit irrigation on yield and water use efficiency and reduce the cost of drip irrigation network materials of corn under sandy soil conditions. El-Hendawy and Schmidhalter, (2010). said that, the water application rates needed to achieve maximum yield and IWUE under limited water applications require the establishment of optimal soil water contents around the emitters without moving the water beyond the active rooting zone or failing to meet the water requirement of the plant. In addition, maize yields under drip irrigation are generally a linear function of the seasonal ET and yields are usually lower if ET is less than optimal. For example, El-Hendawy et al. (2008) found that the decreases in the grain yield of maize drip irrigated for 0.80 and 0.60 ET com-pared to 1.00 ET were approximately 18.0 and $60.0 \%$, respectively. This also indicated that applying water below the full crop-water requirement under the drip irrigation system requires further approaches to mitigate the adverse effects of this water deficit. A potential approach to reduce water deficit-induced crop losses is the exogenous application of osmolytes that do not interfere with enzymatic functions. Kresović et al., 2016. Therefore, reducing irrigation level and improving water use efficiency are critically important to sustainable agriculture. Water-saving irrigation measures can influence crop growth, yield, and WUE. Many techniques have been suggested for improving the yield, WUE and economic return of maize. Some scholars have discussed various water-saving irrigation technologies for reducing agricultural water use. Karasu et al., 2015. Told that, irrigation regimes affect evapotranspiration and maize grain yield. Some studies have suggested that maize yield is a linear function of seasonal evapotranspiration . Liu, et al. 2017 show that by simulated the sensitivity of maize to water at varied stages and the simulation results indicated that the descending order was pollen shedding and silking, tasse lling, jointing, initial grain filling, germination, middle grain filling, late grain filling, and end of grain filling Wang et al. 2014,remmber that Inrecent years, drip irrigation has widely been applied to maize production in subhumid regions like North China Plain Chen et al., 2015 show that Drip irrigation, whereby water is frequently applied to a small area near growing plants, generally 
results in strong crop development while limiting soil evaporation and percolation depth Lifeng $Z$ et al. 2018 said that, the effect of lateral spacing on yield and WUE were influenced by irrigation amounts. Under high irrigation amounts (i.e. 550-700 $\mathrm{mm})$, grain yield and WUE first increased and then decreased as the lateral spacing increased, which showed a higher yield and under lateral spacing of $1.5 \mathrm{~m}$ than that of under $0.7 \mathrm{~m}$ and $2.1 \mathrm{~m}$. Under low irrigation amounts (i.e. $300 \mathrm{~mm}$ ), grain yield and WUE were decreased as the lateral spacing increased. Layout and spacing of drip irrigation laterals has been shown to influence the distribution of soil water content and nitrate, yield formation, and net profits in dripped irrigation systems. Closer lateral spacing usually gives a greater horizontal water content distribution uniformity, crop yield, and water use efficiency (WUE) Chen et al., 2015.

The aim of this study is to determined the effect of drip lateral spaces and the full, and deficit irrigation on corn yield.

\section{MATERIALS AND METHODS}

\section{Experimental Layout}

The experiment was conducted in privet farm (green revolution Km31EgyptAlexandria road. The farm has the latitude of $30^{\circ} 04^{\prime} 37.0 \mathrm{~N}$ the longitude of $30^{\circ} 59^{\prime} 53.5 \mathrm{E}$. Some physical and chemical properties of the soil given in Table (1). The soil of the experimental site is sand. soil $\mathrm{pH}$ values ranged from 6.62 to 6.78 , soil water tension at the field capacity ( 0.1 bar) and at wilting point ( 15 bar), respectively. Mean bulk density varies from 1.4 to $1.6 \mathrm{~g} / \mathrm{cm}^{3}$.

The drip irrigation system consisted of a control unit and distribution lines Fig (1). The control unit of the system contained a disk filter, control valves, pressure gauges and a water flow meter. Distribution lines consisted of polyethylene pipe manifolds for each plot. Drip laterals of $16 \mathrm{~mm}$ in diameter had in-line emitters spaced $0.50 \mathrm{~m}$ apart, each delivering $(4 \mathrm{~L} / \mathrm{h})$ at the pressure of 1 Bar. Each manifold had removable end caps for flushing. The experimental design in three replications.

Irrigation management treatments consist of three different lateral spacings (A: $0.60 \mathrm{~m}, \mathrm{~B}: 1.20 \mathrm{~m}, \mathrm{C}: 1.80 \mathrm{~m}$ ) and two water level ( $\mathrm{I}_{100} \%, \mathrm{I}_{270} \%$ ). In $\mathrm{A}$, one drip lateral was laid out at the center of two subsequent crop rows; in $B$, one lateral at the center of alternative rows; and in C, one drip lateral served three crop rows Fig( 1). For deficit irrigation treatment $I_{70} 30 \%$ less water was applied as compared to $I_{100}$ treatment plots. The plot dimensions were $60 \mathrm{~m}$ by $70 \mathrm{~m}$. A layout of the experimental plots is shown in Fig (1). Plant and soil water measurements and observations were started 18 days after planting, and were terminated on the harvest date. Commercial farm equipment was used for agronomic practices. The experimental field was planted 
with a four-row planting machine at $60 \mathrm{~cm}$ row spacing. Single hybrid (Giza /131) corn was used in this study planted on 2 June 2016.

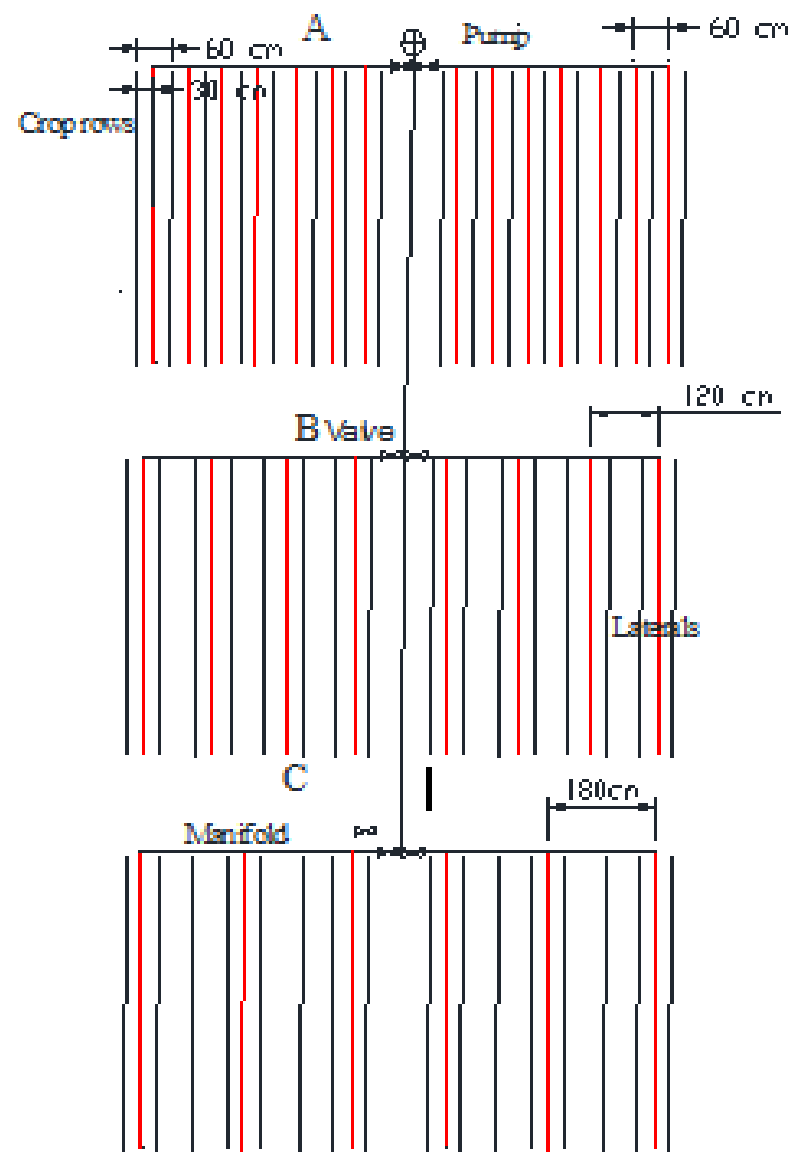

Fig. 1. Experimental Layout

Table1. Physical and Chemical properties of different soil layers of the experimental field.

\begin{tabular}{|c|c|c|c|c|c|c|c|c|c|c|c|c|c|c|}
\hline \multirow{2}{*}{$\begin{array}{l}\text { Soil } \\
\text { depth }\end{array}$} & \multirow{2}{*}{$\begin{array}{l}\text { Sand } \\
\% \\
\end{array}$} & \multirow{2}{*}{$\begin{array}{l}\text { Silt } \\
\% \\
\end{array}$} & \multirow{2}{*}{$\begin{array}{c}\text { Clay } \\
\% \\
\end{array}$} & \multirow{2}{*}{$\begin{array}{l}\text { F.C } \\
\% \\
\end{array}$} & \multirow{2}{*}{$\begin{array}{c}\text { W.P } \\
\%\end{array}$} & \multirow{2}{*}{$\begin{array}{l}\text { Ece } \\
\mathrm{Ds} / \mathrm{m}\end{array}$} & \multirow[t]{2}{*}{ PH } & \multicolumn{4}{|c|}{ Cations } & \multicolumn{3}{|c|}{ Anions } \\
\hline & & & & & & & & $\mathrm{Ca}^{++}$ & $\mathrm{Mg}^{++}$ & $\mathrm{Na}^{+}$ & $k^{+}$ & $\mathrm{HCO}^{-} 3$ & So $4^{-2}$ & $\mathrm{CL}^{-}$ \\
\hline $0-30$ & 58 & 12 & 12 & 40 & 1.19 & 1.13 & 6.68 & 1.62 & 0.53 & 0.63 & 0.10 & 1.79 & 0.4 & 0.62 \\
\hline $30-60$ & 55 & 19 & 26 & 40 & 1.16 & 0.17 & 6.62 & 1.79 & 0.74 & 0.70 & 0.07 & 1.5 & 1.17 & 0.59 \\
\hline-90 & 28 & 18 & 54 & 41 & 1.15 & 0.11 & 6.78 & 2.71 & 0.85 & 0.74 & 0.05 & 1.53 & 1.93 & 0.69 \\
\hline
\end{tabular}

\section{Crop water requirement:s parameters}

Table 2 showing the following value .

Table 2. Crop Water Requirements (CWR), Irrigation Crop Water requirements (ICWR), References Evapotreanspiration(ETo), Evapotreanspiration(ETC) and Crop factor( $\mathrm{K}_{\mathrm{c}}$ )

\begin{tabular}{|c|c|c|c|c|c|c|c|}
\hline Month & \multirow{2}{*}{$\begin{array}{c}\mathrm{ET}_{\mathrm{o}} \\
\mathrm{mm} / \mathrm{day}\end{array}$} & $\mathrm{K}_{\mathrm{c}}$ & \multirow{2}{*}{$\begin{array}{c}\mathrm{ET}_{\mathrm{c}} \\
\mathrm{mm} / \mathrm{day}\end{array}$} & \multicolumn{2}{|c|}{$\begin{array}{c}\mathrm{CWR} \\
\left(\mathrm{m}^{3} / \text { fed./day }\right)\end{array}$} & \multicolumn{2}{|c|}{$\begin{array}{c}\text { ICWR } \\
\left(\mathrm{m}^{3} / \text { fed./day }\right)\end{array}$} \\
\cline { 5 - 8 } & & & & $100 \%$ & $70 \%$ & $100 \%$ & $70 \%$ \\
\hline June & 6.5 & 0.55 & 3.6 & 15 & 10.5 & 16.8 & 11.76 \\
\hline July & 5.1 & 0.95 & 4.8 & 20.3 & 14.21 & 22.4 & 15.68 \\
\hline August & 4.4 & 1.1 & 4.8 & 20.1 & 14.07 & 22.4 & 15.68 \\
\hline September & 4.7 & 1.0 & 4.7 & 19.7 & 13.79 & 22.0 & 15.33 \\
\hline
\end{tabular}


Reference evapotranspiration (ET0, mm/day) was calculated according to the Penman-Monteith (PM) equation as specified by the FAO protocol (Allen et al., 1998) for irrigation scheduling.

As crop evapotranspiration ETc can be calculated as:

$$
\mathrm{ETC}=\mathrm{Kc} \times \mathrm{ET}_{0}
$$

Where:-

$\mathrm{ETc}=$ Crop evapotranspiration $(\mathrm{mm} /$ day $)$,

$\mathrm{Kc}=$ Crop coefficient ranged,

$\mathrm{ET}_{0}=$ Reference crop evapotranspiration ( $\mathrm{mm} /$ day).

In turn the Grass water requirement (GWR), is calculated by multiplying the reference crop evapotranspiration, $\mathrm{ET}_{0}$, by a crop coefficient, $\mathrm{Kc}$ following (Allen et al., 1998).

\section{CWR $=E T C \times 4.2$ \\ ICWR $=C W R \times L R$}

** LR= Leaching Requirements (Assumed 12\%of total applied water)

Calculating water use efficiency (WUE): Water use efficiency WUE) was computed as the ratio of corn grain yield to seasonal water use (Howell et al., 1995).

$$
(\mathrm{WUE}) \mathrm{Kg} / \mathrm{m3}=\frac{\text { Yield }(\mathrm{Kg})}{\text { Water use }(\mathrm{m3})} \times 100
$$

Fertlization: Fertilizer applications were based on soil analysis results and all the plots received the same amount of fertilizer. total $150 \mathrm{Kg} / \mathrm{Fed}$. of Super phosphate $150 \mathrm{Kg} / \mathrm{unit}$ area of Potassium Sulfate $150 \mathrm{Kg}$ of Ammonium Sulfate, which was applied in banding along the rows and then incorporated into the soil.

\section{Dripper Evaluation}

Table (3) and Fig (2): showing the dripper evaluation ( bilt in drip)

Table 3. showing the Dripper Evaluation

\begin{tabular}{|l|c|c|c|c|c|c|}
\hline \multirow{2}{*}{ Dripper } & \multirow{2}{*}{ X ponent } & \multirow{2}{*}{ CV\% } & EU & \multicolumn{3}{|c|}{ Classification according to ASABE } \\
\cline { 5 - 7 } & & & $\%$ & X ponent & C.V\% & EU\% \\
\hline GR & 0.50 & 1.49 & 93 & Turbulent & excellent & excellent \\
\hline
\end{tabular}

CV : Manufacturers coefficient of emitter variation

EU : the emission uniformity \%. 


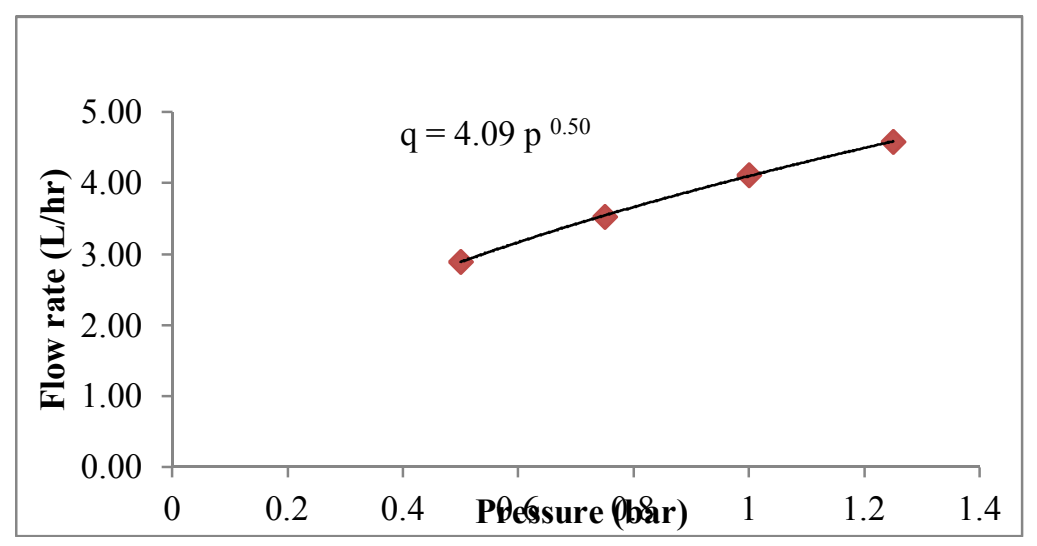

Fig. 2. Flow rate $(q)$ with pressure for $G R$ drippers ( $4 \mathrm{~L} / \mathrm{h})$ performance curve.

\section{RESULTS AND DISCUSSION}

Table (4) and Fig $(3,4,5)$ : showing the following: Dry matter yield, Corn grain yield, Water use, Water use efficiency (WUE) also, show that the highest grain yield was observed in B $I_{1} 100 \%$ treatment as $4916 \mathrm{~kg} /$ fed and the lowest yields was found in the plant row 0.90 m away from the drip lateral in C $I_{2} 70 \%$ treatment as $2504 \mathrm{~kg} /$ fed. These results indicate that, the preferable lateral spacing for corn plant was found to be $1.2 \mathrm{~m}$. The yield from the wider $(\mathrm{C}=1.80 \mathrm{~m})$ dripline spacing with full irrigation $\mathrm{CI}_{1} 100 \%$ (3738 Kg/Fed) was lower, than the yield from the propose dripline spacing B $\mathrm{I}_{1}{ }_{100} \%$ (4916 Kg/Fed) $1.2 \mathrm{~m}$ by $23.9 \%$, while closer dripline spacing (60 $\mathrm{cm}$ ) with full irrigation ( $\left.\mathrm{A} \mathrm{I}_{1} 100 \%\right) 3612 \mathrm{Kg} / \mathrm{Fed}$, reduced the yield by $26.5 \%$ as compared to yield from the superior spacing $(1.2 \mathrm{~m})$. The yield was reduced when the irrigation levels was reduced. Also the data revealed that the grain yield from the corn rows adjacent to the drip lateral $(60 \mathrm{~cm})$ in full irrigation $A I_{1} 100 \%(3612 \mathrm{Kg} / \mathrm{Fed})$ treatment plots were higher than the deficit irrigation plots $A I_{1} 70 \%$ (3192 $\mathrm{Kg} / \mathrm{Fed})$.Also the grain yield a way from the drip line $180 \mathrm{~cm} \mathrm{CI} 270 \%(2504 \mathrm{Kg} / \mathrm{Fe})$ were lower than the yields from corn rows adjacent to the lateral in the deficit irrigation plots $\mathrm{AI}_{2} 70 \%(3192 \mathrm{Kg} / \mathrm{Fe})$ this can be attributed to in the deficit irrigation treatment plots $\left(\mathrm{I}_{70}\right)$, degree of the water stress gradually increased towards the end of the growing season and resulted in reduced crop yields.

This result indicated that one lateral per three rows is not suitable for corn production under the study conditions since insufficient irrigation water is supplied to crops $0.90 \mathrm{~m}$ away from the drip lateral, the lateral spacing of $1.20 \mathrm{~m}$ resulted in higher grain yields than the other two spacings $(0.60$ and $1.80 \mathrm{~m})$. These findings is agree with Yazar et al. (2002), reported that the highest average corn grain yield obtained in the full irrigation treatment using trickle irrigation method was 11,920 $\mathrm{kg} / \mathrm{ha}$. 
Total dry matter varied from 9324 to $13188 \mathrm{~kg} / \mathrm{Fed}$, the highest dry matter was observed in A1 $100 \%$ (13188 kg /Fed) and the lowest in $C_{2} 70 \%(9324 \mathrm{~kg} / \mathrm{Fed})$. The dry matter production under the full irrigation was higher than that under the deficit irrigation treatment. The highest dry matter production was observed in the treatment of one lateral per corn row, this can be attributed to the wetter soil water conditions, which enhanced the vegetative development. Also, Fig (3): show that treatment $\mathrm{CI}_{2} \quad 70 \%$ was the lowest in receiving irrigation water use $1796 \mathrm{~m}^{3} / \mathrm{Fed} /$ seasonal ( $428 \mathrm{~mm} /$ seasonal) in deficit irrigation in compare with the other (A $\left.\mathrm{I}_{1} 100 \%\right)$ $2551 \mathrm{~m}^{3} / \mathrm{Fed} /$ seasonal (607 mm/ seasonal) in non- stress plot (full irrigation).

Table 4. Dry matter yield, Corn grain yield, Water use, Water use efficiency (WUE).

\begin{tabular}{|c|c|c|c|c|c|c|c|c|c|c|}
\hline Treatment & $\begin{array}{l}\text { Period } \\
\text { month }\end{array}$ & $\begin{array}{c}\text { water } \\
\text { use } \\
\mathrm{m}^{\wedge} \mathbf{3} / \text { Fed }\end{array}$ & $\mathbf{E T}_{\mathrm{c}}$ & $\begin{array}{l}\text { Water } \\
\text { use } \\
\text { month } \\
\text { m3 }\end{array}$ & $\begin{array}{l}\text { Operation } \\
\text { time min }\end{array}$ & $\begin{array}{l}\text { Corn } \\
\text { grin } \\
\mathrm{Kg} / \text { Fed }\end{array}$ & $\begin{array}{c}\text { Dray } \\
\text { mater } \\
\mathrm{Kg} / \mathrm{Fed}\end{array}$ & $\begin{array}{c}\text { Water } \\
\text { use } \\
\text { seasonal } \\
\text { m3 }\end{array}$ & $\begin{array}{c}\text { Water } \\
\text { use } \\
\text { seasonal } \\
\text { mm }\end{array}$ & $\begin{array}{l}\text { W.U.E } \\
\mathrm{Kg} / \mathrm{m} 3\end{array}$ \\
\hline \multirow{4}{*}{$\mathrm{AI}_{1} 100 \%$} & June & 16.8 & 15 & 504 & 18 & \multirow{4}{*}{3612} & \multirow{4}{*}{13188} & \multirow{4}{*}{2551} & \multirow{4}{*}{607} & \multirow{4}{*}{1.41} \\
\hline & July & 22.4 & 20.3 & 694.4 & 24 & & & & & \\
\hline & August & 22.4 & 20.1 & 694.4 & 24 & & & & & \\
\hline & September & 22 & 19.7 & 658 & 24 & & & & & \\
\hline \multirow{4}{*}{$\mathrm{AI}_{2} 70 \%$} & June & 11.8 & 15 & 352.8 & 13 & \multirow{4}{*}{3192} & \multirow{4}{*}{11424} & \multirow{4}{*}{1796} & \multirow{4}{*}{428} & \multirow{4}{*}{1.77} \\
\hline & July & 15.7 & 20.3 & 491.7 & 17 & & & & & \\
\hline & August & 15.7 & 20.1 & 491.7 & 17 & & & & & \\
\hline & September & 15.3 & 19.7 & 460 & 17 & & & & & \\
\hline \multirow{4}{*}{$\mathrm{BI}_{1100} \%$} & June & 16.8 & 15 & 504 & 36 & \multirow{4}{*}{4916} & \multirow{4}{*}{11130} & \multirow{4}{*}{2551} & \multirow{4}{*}{607} & \multirow{4}{*}{1.92} \\
\hline & July & 22.4 & 20.3 & 694.4 & 48 & & & & & \\
\hline & August & 22.4 & 20.1 & 694.4 & 48 & & & & & \\
\hline & September & 22 & 19.7 & 658 & 47 & & & & & \\
\hline \multirow{4}{*}{$\mathrm{BI}_{2} 70 \%$} & June & 11.8 & 15 & 352.8 & 25 & \multirow{4}{*}{3360} & \multirow{4}{*}{11422} & \multirow{4}{*}{1796} & \multirow{4}{*}{428} & \multirow{4}{*}{1.87} \\
\hline & July & 15.7 & 20.3 & 491.7 & 34 & & & & & \\
\hline & August & 15.7 & 20.1 & 491.7 & 34 & & & & & \\
\hline & September & 15.3 & 19.7 & 460 & 33 & & & & & \\
\hline \multirow{4}{*}{$\mathrm{CI}_{1100} \%$} & June & 16.8 & 15 & 504 & 55 & \multirow{4}{*}{3738} & \multirow{4}{*}{10248} & \multirow{4}{*}{2551} & \multirow{4}{*}{607} & \multirow{4}{*}{1.46} \\
\hline & July & 22.4 & 20.3 & 694.4 & 74 & & & & & \\
\hline & August & 22.4 & 20.1 & 694.4 & 74 & & & & & \\
\hline & September & 22 & 19.7 & 658 & 73 & & & & & \\
\hline \multirow{4}{*}{$\mathrm{CI}_{270} \%$} & June & 11.8 & 15 & 352.8 & 38 & & & & & \\
\hline & July & 15.7 & 20.3 & 491.7 & 52 & 000 & 0207 & 1770 & 隹 & 120 \\
\hline & August & 15.7 & 20.1 & 491.7 & 52 & $\angle 50 L$ & 9324 & $1 / 96$ & 428 & 1.39 \\
\hline & September & 15.3 & 19.7 & 460 & 51 & & & & & \\
\hline
\end{tabular}

Water use in the rows next to the lateral in the treatment $C \mathrm{I}_{2} 70$ was higher than the water use at distant rows $(0.90 \mathrm{~m}$ from the lateral). This result indicated that 
one lateral per three rows is not suitable for corn production under the study conditions since insufficient irrigation water is supplied to crops $0.90 \mathrm{~m}$ away from the drip lateral.

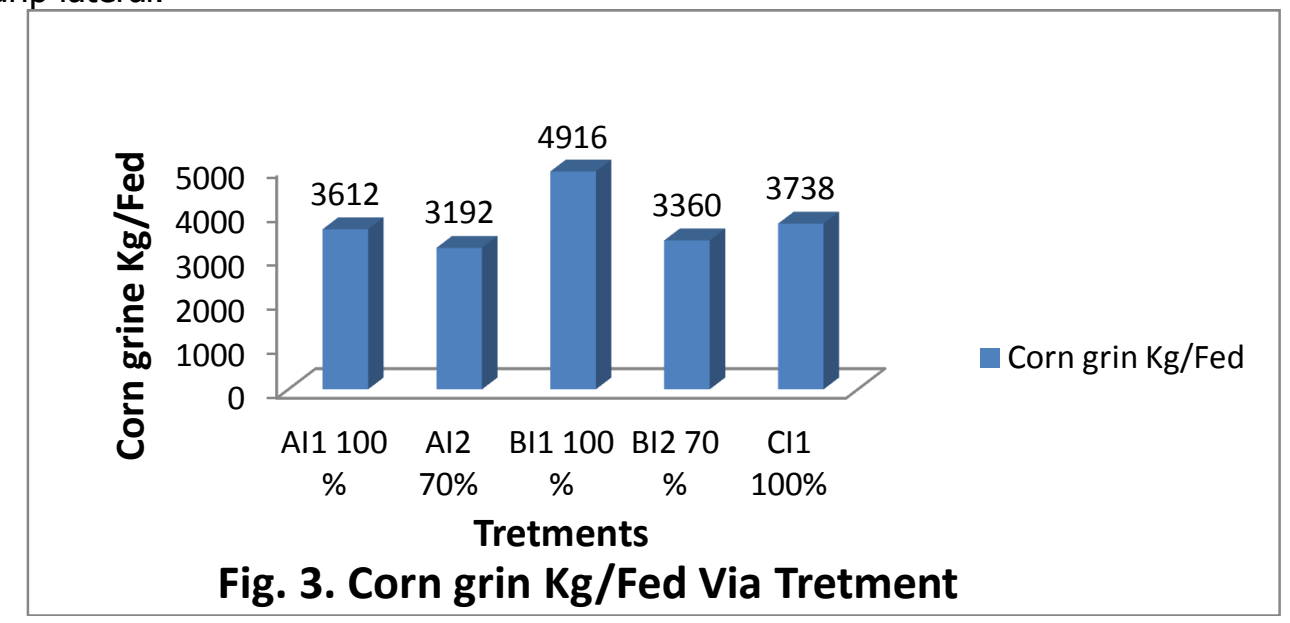

The date in Fig. 4 :showing that the highest water use efficiency (WUE), 1.87 $\mathrm{kg} / \mathrm{m}^{3}$, was obtained in treatment $B I_{2} 70 \%$ while the lowest one was found in treatment $C \mathrm{I}_{2} 70 \%\left(1.39 \mathrm{~kg} / \mathrm{m}^{3}\right)$. In general, WUE values decreased with increasing water use.

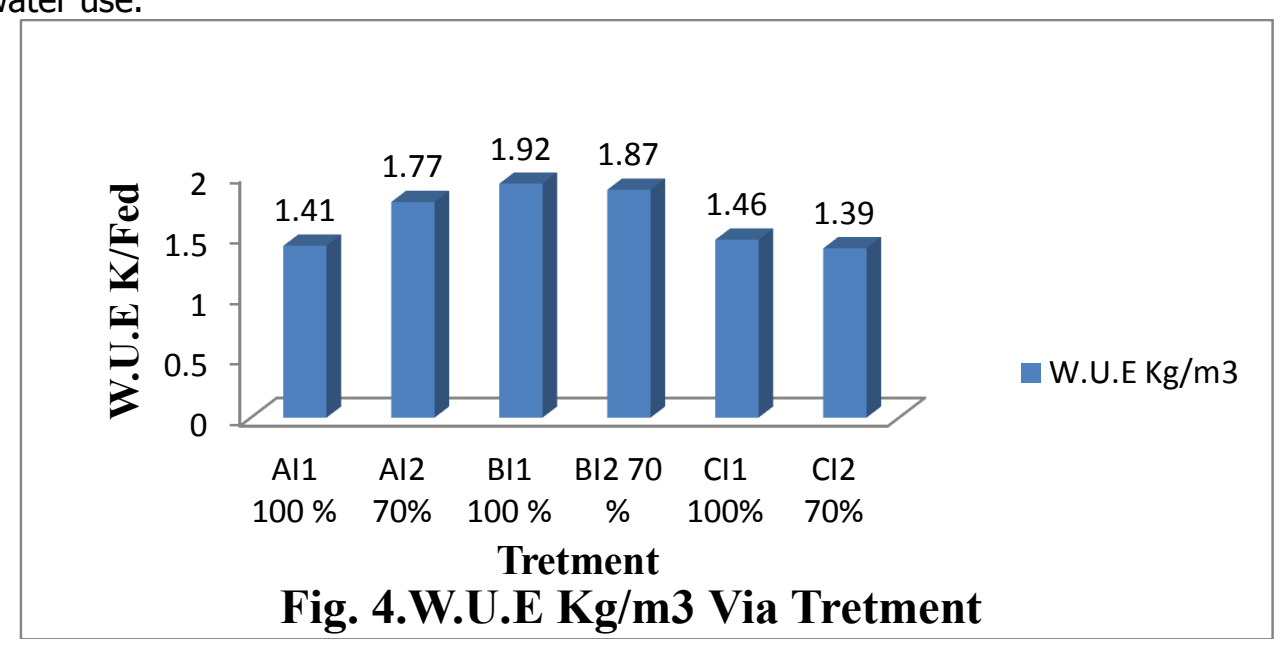

Fig. 5 shows the relationship between operating hours and treatments. From the figure it is be observed that the operating hours of treatments $\mathrm{CI}_{1100} \%$ and $\mathrm{CI}_{2} 70$ $\%$ were higher than the rest of the treatments $\left(A I_{1} 100 \%, A I_{170} \%, B I_{1} 100 \%\right.$ and $B I_{1}$ $70 \%)$ in order to reach the actual water needs of the plant. On the margin of research the highest grain yield per cob was observed in $B_{1} 100$ at $184.8 \mathrm{~g}$, and the lowest was found in $C_{2} 70$ at $143.1 \mathrm{~g}$. The highest grain number per cob was observed in $B_{1} 100$ (482), and the lowest was found in $C_{2} 70$ (501). The research indicated that the grain 
yield per cob and grain number per cob was found to be relatively higher in full irrigation treatments as compared to the deficit irrigation cases.

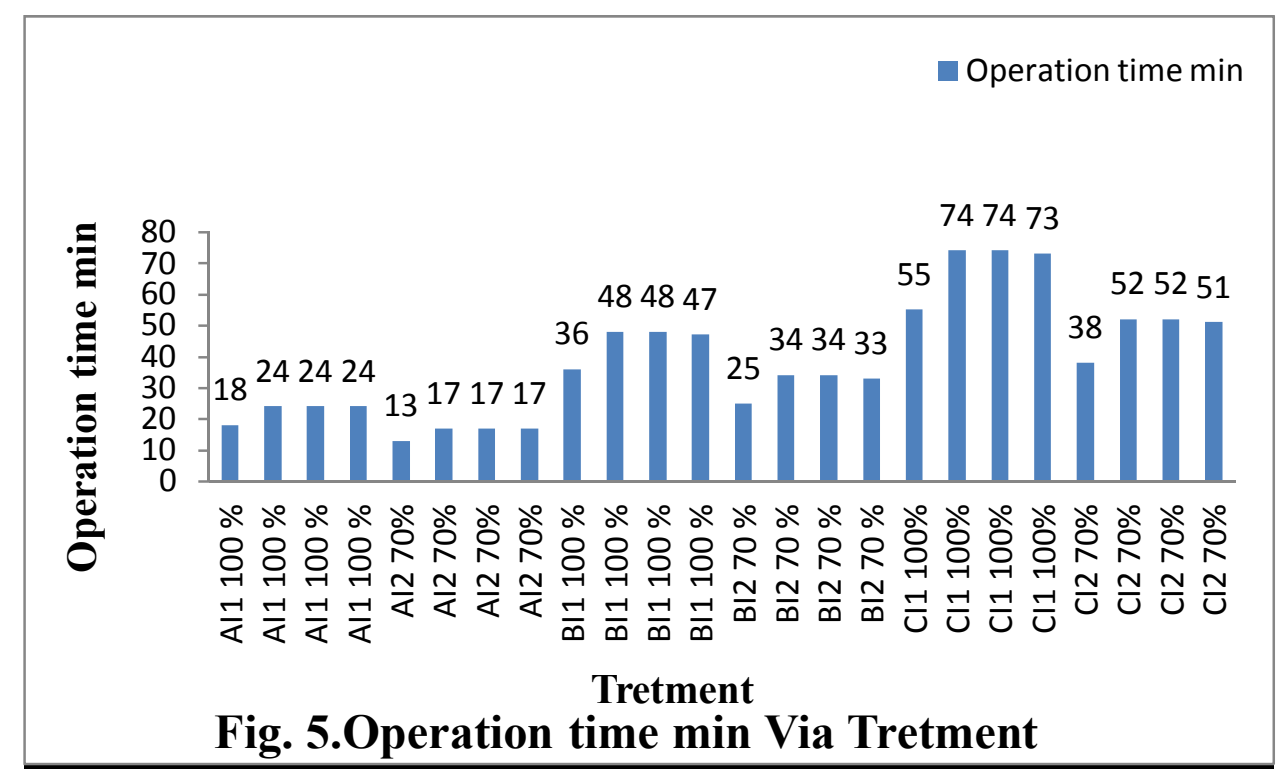

\section{CONCLUSION}

This study was carried out to evaluate the effects of full and deficit irrigation and different lateral spacing on yield and yield components of corn. According to results, preferable lateral spacing for corn plant was found to be $1.20 \mathrm{~m}$, which produced the maximum yield of $4912 \mathrm{~kg} /$ Fed. In other words, flow rate $8 \mathrm{~L} / \mathrm{h} / \mathrm{m}$, one drip lateral laid out at the center of two crop rows is recommended for the corn producers in the region. Grain yields away from the drip line $(0.90 \mathrm{~m})$ were lower than the yields from corn rows adjacent to the lateral both in the full and deficit irrigation plots. Non-uniformity of grain yield increased with deficit irrigation in the wider lateral spacing. Considering that the cost of the pipes (all tubing and laterals included) is about $40 \%$ of the total cost, one drip lateral per two crop rows would result in considerable saving in total installation cost of a drip system. The research results also revealed that a lateral spacing of $1.80 \mathrm{~m}$ (one lateral per three corn rows) is not suitable for the drip irrigated corn production under the Egyptian climatic conditions.

\section{REFERENCES}

1- Allen, R. G.; L. S. Pereira; D. Raes; and M. Smith. 1998. Crop evapotranspiration. Guidelines for computing crop water requirements. FAO Irrigation and Drainage. Paper No. 56, FAO, Rome, Italy.

2- Camp, C.R., : 1998. Subsurface drip irrigation: a rewiew. Trans. ASAE 41 (5) : 1353-1367. 
3- Chen, R., Cheng, W.H., Cui, J., Liao, J., Fan, H., Zheng, Z., and F.Y., Ma. : 2015 Lateral spacing in drip-irrigated wheat The effects on soil moisture, yield and water use efficiency. Field Crops Res. 179: 52-62.

4- El-Hendawy, S.E., Abd El-Lattief, E.A., Ahmed, A.S., and U., Schmidhalter : 2008. Irrigation rate and plant density effects on yield and water use efficiency of dripirrigated corn. Agric. Water Manage. 95: 836-844.

5- El-Hendawy, S.E., and U., Schmidhalter.: 2010. Optimal coupling combinations between irrigation frequency and rate for drip-irrigated maize grown on sandy soil. Agric. Water Manage. 97: 439-448.

6- Hanson, B., Schwankl, L., Grattan, S.R., and T., Prichard.: 1994. Drip irrigation for row crops. Water Management Handbook Series 93-05. University of California, Davis, CA.

7- Howell, T. A., Steiner, J. L., Schneider, A. D., and Evett, S. R. :1995b "Evapotranspiration of irrigated winter wheat-Southern High Plains." Trans. ASAE,38 3 : 745-759.

8- Hussein M. Al-Ghobari, and A. Z. Dewidar : 2018. Integrating deficit irrigation into surface and subsurface drip irrigation as a strategy to save water in arid regions. Agricultural Water Management 209 : 55-61.

9- Karasu, A., Kuscu, H., Oz, M., and G., Bayram : 2015. The effect of different irrigation water amounts on grain yield: yield components and some quality parameters of silage maize (Zea mays indentata Sturt.) in Marmara region of Turkey. Not. Bot. Horti Agrobot. 43 :138-145.

10- Kresović, B., Tapanarova, A., Tomić, Z., Životić, L., Vujović, D., Sredojević, Z., and B. Gajić : 2016. Grain yield and water use efficiency of maize as influenced by different irrigation regimes through sprinkler irrigation under temperate climate. Agric. Water Manage. 169 : 34-43.

11- Kruse, E and .G., I.Israeli : 1987. Evaluation of a subsurface drip irrigation system. Presented at the 1987. Summer Meeting, Engi., ASAE Paper No. 872034. ASAE, St. Joseph, Michigan: 21.

12- Lamm, F.R., Stone, L.R., Manges, H.L., and D.M., O'Brien : 1997. Optimum lateral spacing for drip-irrigated corn. Trans. ASAE 40 (4): 1021-1027.

13- Lifeng Z,b , Jianqiang $H$, Zhijuan Q, Miles D, Yufeng Z and T. Zhanga : 2018 Effects of lateral spacing for drip irrigation and mulching on the distributions of soil water and nitrate, maize yield, and water use efficiency Agri.,Water Manag., 190-200 191 
14- Liu Y, Yang H S, Li Y, Yan H J, and J S. Li : 2017 Modeling effects of plastic film mulching on irrigated maize yield and water use efficiency in sub-humid Northeast China. International Journal of Agric., and Biolog., Engi., (10): 69-84.

15- Liu Y, Yang H S, Li J S, Li Y F and Y H -Jun : 2018 Estimation of irrigation requirements for drip-irrigated maize in a sub-humid climate Journal of Integrative Agricu., 17(3): 677-692

16- Longo, F.D., and T.D., Spears : 2003. Water scarcity and modern irrigation. Valmont Water Management Group. Valmont Industires, Inc., Valley, Nebraska, USA.

17- Sefer B., Attila Y. and G. S. Mansuro_lu1: 2011. Effects of different drip irrigation levels on yield and some agronomic characteristics of raised bed planted corn. African Journal of Agric., Research Vol. 6(23), : 5291-5300.

18- Shiklomanov, I.,:1998 Pictures of the future: a review of global water resources projections. In: Gleick, P.H. (Ed.), The World's Water 2002-2001. Island Press, Washington, DC, p. 53.

19- Spurgeon, W.E., and T.P. Makens :1991 Irrigation management for LEPA systems. ASAE Paper No. 91-2519. St. Joseph, Mich. ASAE.

20- Wang Z, Li J, and Y Li :2014 Simulation of nitrate leaching under drip system uniformities and precipitation patterns during the growing season of maize in North China Plain. Agri., Water Manag., 142 : 19-28.

21- Yazar, A., Sezen, S.M., and B. Gencel. 2002. Drip irrigation of corn in the Southeast Anatolia Project (GAP) area in Turkey. Irrig. Drain. 51: 293-300. 


\section{تاثير المسافة بين خطوط الرى بالتنقيط}

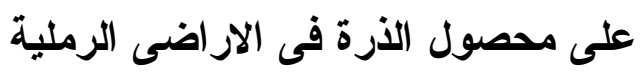

احمد عبد العاطي حسين ، احمد صلاح حسن محمد و طارق سالم محمد

$$
\text { معهد بحوث الهندسة الزراعية _مركز البحوث الزراعية _دقي _ جيزة _ مصر }
$$

هذه الدراسة نم تتفيذها لتقدير تاثير المسافة بين خطوط الرى بالتتقيط على محصول الذرة فى الار اضى الرملية فى حالة الرى الكامل والناقص على الانتاجية وكفاءة إستخدام المياة وتقليل

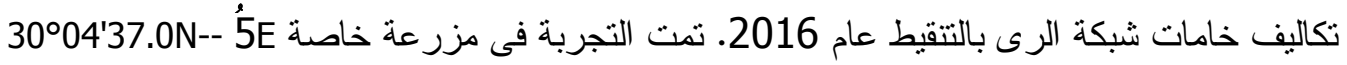

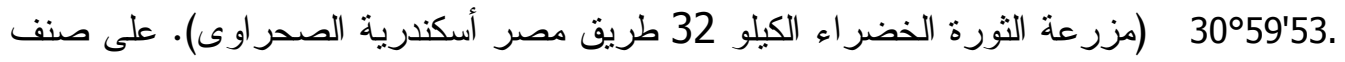

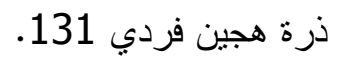

وكان تخطيط التجربة علي النحو التالي : ثلاث مسافات بين خطوط التنقيط (A=60، A A سنتيمنز ) وكميات مياة C=180،B= أظهرت الدر اسة أن أعلى أستخدام للمياة فى الموسم تحقق من المعاملة ( A I I I

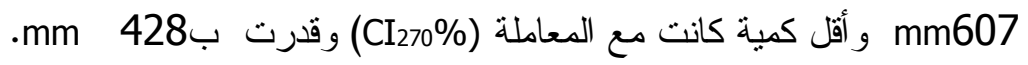

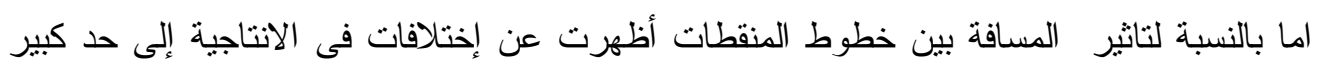
وقدرت أعلى إنتاجية ( 4916 كجم /فدان) للمعاملة Cm 120 BI المنقطات) وأقل إنتاجية (2604 كجم / فدان) للمعاملة CI270\% 180 (cm مسافة بين خطوط (المنقطات).

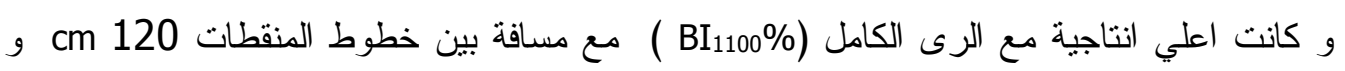
. و لذلك تنين ان انسب مسافة بين خطوط المنقطات لمحصول الذرة cm 120 . وان ، أعلى كفاءة

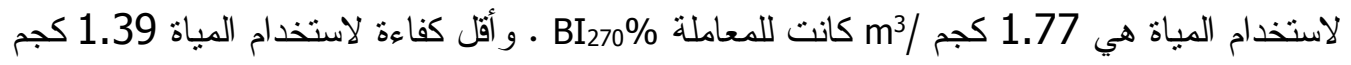

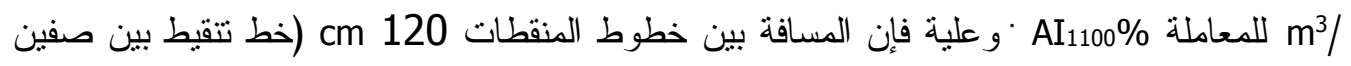

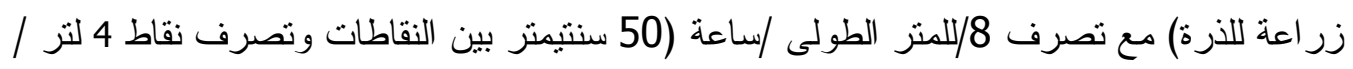

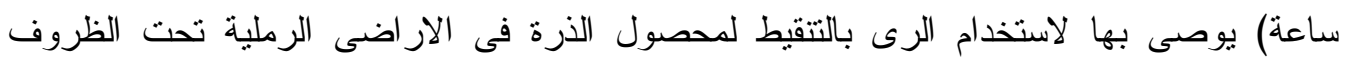
المصرية. 
